\title{
Penentuan Prioritas Penanganan Kerusakan Jalan Di Kota Dili Timor Leste Berdasarkan Kondisi Kerusakan Perkerasan Jalan (Studi Kasus: Jalan Aikakeu Laran, Jalan Bebonuk, Jalan Comoro, dan Jalan Becora)
}

\author{
Frans De Jesus Babo, ${ }^{1, *}$, Indrasurya B. Mochtar ${ }^{1}$, Catur Arif Prastyanto ${ }^{1}$ \\ Departemen Teknik Sipil, Institut Teknologi Sepuluh Nopember, Surabaya ${ }^{1}$ \\ Koresponden*, Email: fransbabo69@gmail.com
}

\begin{tabular}{|c|c|c|}
\hline \multicolumn{2}{|c|}{ Info Artikel } & Abstract \\
\hline Diajukan & 25 Juli 2019 & Road It is a very important infrastructure in the transportation sector. Good road conditions \\
\hline Diperbaiki & 2 Agustus 2019 & will facilitate the mobility of the population in conducting economic activities and other social \\
\hline Disetujui & 2 Agustus 2019 & $\begin{array}{l}\text { activities. The road maintenance program must be carried out by the Timor Leste government. } \\
\text { With the many obstacles and problems, such as budget constraints, proposals from the people } \\
\text { who continue to enter the Public Works Agency, the road network maintenance program } \\
\text { planning is needed in stages by prioritizing the handling of road damage. The purpose of the } \\
\text { priority is to deal with road damage on the four road sections in Dili City, then the data needed } \\
\text { are Visual Damage Value, Equivalent Axle Load and road functions. Based on the results and }\end{array}$ \\
\hline $\begin{array}{l}\text { Keywords: } 1 \\
\text { pavement do } \\
\text { conditions }\end{array}$ & $\begin{array}{l}\text { dling road } \\
\text { tvement }\end{array}$ & $\begin{array}{l}\text { street damage assessment of the analysis to determine the priority of treatment, the results are } \\
\text { observed, the priority that needs to be improved is the Comoro road section with EAL amount } \\
\text { maximum } 11691.82 \text {. }\end{array}$ \\
\hline
\end{tabular}

Abstrak

Jalan Merupakan prasarana yang sangat penting dalam sektor perhubungan. Kondisi jalan yang baik akan memudahkan mobilitas penduduk dalam mengadakan kegiatan ekonomi dan kegiatan sosial lainnya. Program pemeliharaan jalan harus dilakukan oleh pemerintah Timor Leste. Dengan banyaknya kendala dan permasalahan, seperti keterbatasan anggaran, usulan dari masyarakat yang terus masuk pada dinas pekerjaan umum, maka diperlukan perencanaan program pemeliharaan jaringan jalan secara bertahap dengan penentuan prioritas penanganan kerusakan jalan. Tujuan dari proritas penanganan kerusakan jalan pada keempat ruas jalan yang ada di Kota Dili tersebut adalah menggunakan data yang dibutuhkan nilai kerusakan visual, equivalent axle load dan fungsi jalan. Berdasarkan hasil analisis dan evaluasi kerusakan jalan untuk menentukan prioritas

Kata kunci: prioritas penanganan kerusakan perkerasan jalan, kondisi perkerasan jalan. penanganan didapat hasil bahwa jalan yang diamati dan prioritas yang perlu diperbaiki adalah ruas jalan Comoro dengan nilai total EAL maksimum 11691,82.

\section{Pendahuluan}

Jalan Merupakan prasarana yang sangat penting dalam sektor perhubungan. Kondisi jalan yang baik akan memudahkan mo-bilitas penduduk dalam mengadakan kegiatan ekonomi dan kegiatan sosial lainnya[1]. Selain itu juga di dalam penentuan prioritas penanganan kerusakan perkerasan jalan di kota Dili Timor Leste sebagai ruas jalan arteri, kolektor, lokal dan lingkungan yang hasilnya dapat me-menuhi kebutuhan masyarakat sebagai pengguna jalan bukanlah pekerjaan yang mudah, lebih-lebih terbatas pada keterbatasan anggaran[2]. Berdasarkan kondisi tersebut, maka penelitian ini menentukan prioritas penanganan jalan berdasarkan penen-tuan prioritas penanganan kerusakan jalan dengan menggunakan data nilai kerusakan visual, equivalent axle load dan fungsi jalan. Dengan semakin meningkatnya ting-kat volume kendaraan dan umur pelayanan, jaringan jalan cenderung mengalami penurunan kondisi yang dapat dilihat dari tingkat kerusakan pada perkerasan jalan tersebut. Agar tingkat kerusakan jalan dapat diminimalkan dan layak digunakan oleh pengguna jalan, jaringan jalan tersebut perlu dikelola agar dapat berfungsi dengan baik untuk masa pelayanan yang panjang. Keterbatasan anggaran yang tersedia dalam Anggaran Pendapatan dan Belanja Negara menjadi kendala pemerintah dalam melaksanakan penanganan tiap ruas jalan yang ada di kota Dili Timor Leste[3]. Selain itu, ketersediaan sumber daya manusia dan peralatan-peralatan yang terbatas juga mempengaruhi kinerja pemerintah dalam kegiatan pemeliharaan tersebut. Oleh sebab itu, perlu adanya kebijakan dan perencanaan yang efektif dari pemerintah dalam penanganan infrastruktur jaringan jalan baik pemerintah pusat maupun daerah di kota Dili Timor Leste. Pemerintah sebagai pengguna anggaran perlu menentukan perencanaan yang tepat dalam penentuan prioritas penanganan jalan agar jaringan jalan berfungsi dengan baik dalam meningkatkan perkembangan ekonomi pembangunan nasional[4]. 


\section{Metodologi}

Metode yang digunakan pada penelitian ini adalah Metode[5]. Berikut metode penelitian yang tercantum pada Tabel 1, Tabel 2, dan Lampiran 1.

Tabel 1. Jenis Kerusakan Perkerasan Jalan dan Faktor Pengalinya

\begin{tabular}{clc}
\hline Kategori & $\begin{array}{l}\text { Jenis Kerusakan Permukaan } \\
\text { Jalan }\end{array}$ & $\begin{array}{c}\text { Faktor } \\
\text { Pengali }\end{array}$ \\
\hline Kategori I & $\begin{array}{l}\text { Potholes } \\
\text { Ravelling-Weathering, } \\
\text { Alligator Cracking \& Profile }\end{array}$ & 6 \\
Kategori II & $\begin{array}{l}\text { Distortion } \\
\text { (Depression, Corrugation, } \\
\text { Up-Heavel, Shoving) } \\
\text { Kategori III }\end{array}$ & $\begin{array}{l}\text { Transverse Cracks, } \\
\text { Longitudinal Cracks, } \\
\text { Block Cracks, Rutting } \\
\text { Kategori IV }\end{array}$ \\
$\begin{array}{l}\text { Pacthing, Flushing, Edge } \\
\text { Cracking }\end{array}$ \\
\hline
\end{tabular}

Contoh Pengisian Form Penilaian Kondisi Perkerasan Jalan dan Drainase Dapat dilihat pada Lampiran 1.

Untuk mengolah dan menganalisis data maka hal-hal yang akan perlu dilakukan adalah sebagai berikut :

1. Survey kerusakan visual (KV) yaitu kegiatan survei dilakukan untuk mengetahui kerusakan perkerasan jalan secara visual untuk menentukan Nilai Kerusakan Visual (KV). Mekanisme survei tersebut dengan tahapan sebagai berikut :

- Survey dilakukan dengan mengendarai sepeda motor secara perlahan

- Survei mencatat kerusakan perkerasan jalan

- Pencatatan pada setiap segmen sepanjang $250 \mathrm{~m}$ setiap lajur

2. Riding Quality (RQ)

Riding Quality (RQ) adalah untuk mengetahui tingkat kenyamanan permukaan jalan oleh pengguna kendaraan. Mekanisme surveinya adalah sebagai berikut :

- RQ dilakukan di dalam kendaraan roda 4 yang cukup layak untuk berkendaraan

- RQ dilakukan sepanjang lajur tetapi pencatatannya pada setiap segmen jalan

- Besaran RQ dapat dilihat pada Tabel 1.

3. Kondisi Drainase

Survei kondisi drainase dilakukan untuk mengetahui kinerja drainase yang sangat berpengaruh terhadap perkerasan jalan. Mekanisme surveinya adalah sebagai berikut :

- Survei dilakukan bersamaan survey visual
- Form yang digunakan seperti pada Tabel 1.

- Nilai total kondisi drainase adalah penjumlahan dari masing-masing kerusakan

Jenis penanganan yang dilakukan terhadap kerusakan perkerasan jalan dapat dilihat pada Tabel 4.

Tabel 4. Jenis Penanganan Nilai Kerusakan Visual Perkerasan Jalan

\begin{tabular}{|c|c|c|c|c|}
\hline \multirow[b]{3}{*}{ Jenis Penanganan } & \multicolumn{4}{|c|}{ Nilai Kerusakan Visual (NKV) } \\
\hline & \multicolumn{3}{|c|}{ Kelas Jalan } & \multirow[b]{2}{*}{ Lokal } \\
\hline & $\begin{array}{c}\text { Utama/ } \\
\text { Arteri } \\
\text { Tol }\end{array}$ & $\begin{array}{c}\text { Arteri } \\
\text { Non Tol }\end{array}$ & Kolektor & \\
\hline Tanpa Perawatan & $0-20$ & $0-20$ & $0-30$ & $0-40$ \\
\hline $\begin{array}{l}\text { Perawaatan Ringan } \\
\text { Perawatan }\end{array}$ & $21-30$ & $21-40$ & $31-60$ & $41-80$ \\
\hline $\begin{array}{l}\text { Menengah (Sealing } \\
+ \text { Patching) }\end{array}$ & $31-50$ & $41-70$ & $61-80$ & $81-120$ \\
\hline Overlay $5 \mathrm{~cm}$ & $51-80$ & $71-100$ & $81-120$ & $121-160$ \\
\hline Overlay $10 \mathrm{~cm}$ & $81-100$ & $101-120$ & $121-160$ & $161-180$ \\
\hline Rekonstruksi & $>100$ & $>120$ & $>160$ & $>180$ \\
\hline $\begin{array}{l}\text { Catatan : Batasan IP } \\
\text { (IPf) }\end{array}$ & 2.5 & $\begin{array}{c}2.00 \& \\
2.50\end{array}$ & $\begin{array}{c}1.50 \& \\
1.75\end{array}$ & 1.25 \\
\hline
\end{tabular}

Sumber: I. S. Mochtar dan Dirgolaksono[5]

Jenis penanganan yang dilakukan terhadap kondisi kualitas drainase jalan dapat dilihat pada Tabel 5.

Tabel 5. Total Nilai Jenis Penanganan Kondisi Kualitas Drainase Jalan

\begin{tabular}{cc}
\hline Total Nilai Drainase & Penanganan Drainase \\
\hline $0-5$ & Tak Perlu Pemeliharaan \\
$15-25$ & Pemeliharaan Ringan \\
$16-25$ & Pemelihraan Sedang \\
$>25$ & Pemeliharaan Berat \\
\hline
\end{tabular}

1. Nilai Kerusakan Visual (NKV) Jalan dan Drainase

Perhitungan nilai kerusakan visual (NKV) ruas jalan Aikakeu Laran yaitu ruas jalan tanpa median dengan dua lajur antara

lajur kiri dan lajur kanan jalan perseksi panjang jalan nilai total rata-ratanya adalah 63,21 dan nilai total rata-rata kualitas drainase perseksi panjang jalan adalah 21,00, ruas jalan Bebonuk yaitu ruas jalan tanpa median dengan dua lajur jalan antara lajur kiri dan lajur kanan rata-rata perseksi panjang jalan nilai total rata-ratanya adalah 36,29 dan nilai total rata-rata kualitas drainase perseksi panjang jalan adalah 14,67, ruas jalan Comoro ada empat lajur dibagi menjadi dua bagian perseksi panjang jalan nilai total rata-rata untuk lajur kiri arah monument Nicolau Lobato ke Landmark Plaza adalah 15,97 dan nilai total rata-rata drainase adalah 2,31, untuk lajur kanan arah Lanmark Plaza ke Monumen Nicolau Lobato nilai rata perseksi Panjang jalan adalah 12,58 dan nilai total rata-rata kualitas drainase adalah 2,38 dan ruas 
jalan Becora yaitu ruas jalan tanpa median antara lajur kiri dan kanan jalan total nilai rata-rata perseksi Panjang jalan adalah 8,61 dan total nilai rata-rata kualitas drainase adalah $1,50[6]$.

\section{Evaluasi Nilai EAL Perkerasan Jalan}

Nilai Equivalent Axle Load (EAL) keempat ruas jalan akan diambil nilai total EAL yang terbesar. Hasil perhitungannya sesuai dengan Tabel 6, Tabel 7, Tabel 8, dan Tabel 9 [7],[8].

\section{Hasil Penelitian}

\section{A. Evaluasi Nilai EAL Perkerasan Jalan}

Nilai Equivalent Axle Load (EAL) keempat ruas jalan akan diambil nilai total EAL yang terbesar. Hasil perhitungannya sesuai dengan Tabel 6, Tabel 7, Tabel 8 dan Tabel 9 [7].

Dari hasil analisa data ada beberapa kondisi yang dapat menyebabkan kerusakan jalan untuk Ruas Jalan Aikakeu Laran pada lajur jalan L1 dan L2:

1. Dari perhitungan nilai EAL di atas LHR truck relatif kecil, NKV kecil, tetapi di lapangan kerusakan pada Ruas Jalan Aikakeu Laran terjadi rusak parah, ini bisa karena kondisi saluran tidak berfungsi dengan baik sehingga terjadi genangan air diatas permukaan jalan pada saat musim hujan, disamping itu niali $\sum E A L$ dari L2 > L1, sehingga traffic juga memiliki kontribusi yang agak besar pada kerusakan jalan ini.

2. Perencanaan subdrain yang baru untuk pemeliharaan ruas jalan, baik yang rusak berat maupun rusak ringan.

Dari hasil analisa data ada beberapa kondisi yang dapat menyebabkan kerusakan jalan untuk Ruas Jalan Bebonuk pada lajur jalan L3 dan L4:

1. Dari perhitungan nilai EAL di atas LHR truck relatif kecil, NKV kecil, tetapi di lapangan kerusakan pada ruas jalan Bebonuk terjadi rusak sedang, ini bisa karena kondisi saluran berfungsi dengan baik sehingga terjadi genangan air diatas permukaan jalan pada saat musim hujan, disamping itu nilai $\sum E A L$ dari L3 > L4, sehingga traffic juga memiliki kontribusi yang agak besar pada kerusakan jalan ini.

2. Perencanaan subdrain yang baru untuk pemeliharaan ruas jalan, baik yang rusak berat maupun rusak ringan

Pada Tabel 7 Ruas Jalan Comoro adalah Ruas Jalan yang menggunakan median jalan sehingga dibagi menjadi 4 lajur dan nilai $\sum E A L$ diambil yang tertinggi.

Dari hasil analisa data ada beberapa kondisi yang dapat menyebabkan kerusakan jalan untuk Ruas Jalan Comoro pada lajur jalan L5 dan L6, L7 dan L8:
1. Dari perhitungan nilai EAL di atas LHR truck relatif tinggi, NKV kecil, tetapi di lapangan kerusakan pada ruas jalan Comoro terjadi rusak ringan, kondisi saluran berfungsi dengan baik, disamping itu niali $\sum$ EAL dari L7\&L8 > L5\&L6, sehingga traffic juga memiliki kontribusi yang agak besar pada kerusakan jalan ini.

2. Perencanaan subdrain yang baru untuk pemeliharaan ruas jalan, baik yang rusak berat maupun rusak ringan

Dari hasil analisa data ada beberapa kondisi yang dapat menyebabkan kerusakan jalan untuk Ruas Jalan Becora pada lajur jalan L9 dan L10:

1. Dari perhitungan nilai EAL di atas LHR truck relatif tinggi, NKV kecil, tetapi di lapangan kerusakan pada ruas jalan Comoro terjadi rusak ringan, kondisi saluran berfungsi dengan baik, disamping itu niali $\sum$ EAL dari L9 $>$ L10, sehingga traffic juga memiliki kontribusi yang agak besar pada kerusakan jalan ini.

2. Perencanaan subdrain yang baru untuk pemeliharaan ruas jalan, baik yang rusak berat maupun rusak ringan

\section{B. Prioritas Penanganan Kerusakan Jalan}

Hasil nilai rekapitulasi Equivalent Axle Load (EAL) untuk prioritas penanganan dari keempat ruas jalan dikota Dili Timor Leste tertera pada Tabel 10 [8].

Tabel 10 Hasil rekapitulasi nilai Total EAL

\begin{tabular}{lcc}
\hline \multirow{2}{*}{ Ruas Jalan } & $\begin{array}{c}\sum \text { EAL } \\
\text { Lajur Kiri } \\
\text { Jalan }\end{array}$ & $\begin{array}{c}\sum \text { EAL } \\
\text { Lajur Kanan Jalan }\end{array}$ \\
\hline Aikakeu Laran & 4805.1 & 5153.94 \\
Bebonuk & 5044.84 & 3589.22 \\
Comoro & 10594.8 & 11691.82 \\
Becora & 8012.35 & 4081.61 \\
\hline
\end{tabular}

Sumber: Hasil Penelitian 2018

Dari nilai rekapitulasi diatas diambil nilai total EAL yang terbesar dari keempat ruas jalan tersebut, Sehingga untuk melakukan prioritas penanganan terhadap kerusakan perkerasan jalan yang ada di kota Dili Timor Leste secara efektif dan tepat. Maka ruas jalan yang diambil untuk prioritas penanganannya adalah ruas jalan Comoro dimana dengan total EAL lajur kiri 10594.80 dan lajur kanan total EAL 11691.82.

\section{Simpulan}

Berdasarkan hasil penilitian ini maka dapat disimpulkan faktor-faktor yang menyebabkan terjadinya kerusakan keeempat ruas jalan antara Aikakeu Laran, Bebonuk, Comoro dan Becora dalam waktu relatif singkat dibandingkan dengan umur rencana atau kerusakan dini. 
Kerusakan dini pada keempat ruas jalan yang ada dikota Dili Timor Leste adalah pengaruh dari kondisi drainase yang tidak berfungsi dengan baik sehingga menyebabkan genangan air di permukaan jalan serta disamping itu pula total EAL yang relative tinggi dan Wt18 lebih besar 7 Juta sehingga traffik berpengaruh juga terhadap kerusakan dini pada perkerasan jalan tersebut.

Untuk prioritas penanganan terjadinya kerusakan pada keempat ruas jalan yang ada di Kota Dili Timor Leste maka diambil nilai total EAL yang terbesar.

\section{Daftar Pustaka}

[1] H. Simangunsong dan P. Eliza, "Studi Kasus ( Jalan Dr Wahidin - Kebon Agung) Metode Pavement Condition Index ( PCI )," E-Journal Universitas Atmajaya Vol. 1, no. 1994, pp. 16-18, 2014.

[2] Jatmiko Budi, L. Djakfar, dan A. Wicaksono, "Penentuan Prioritas Pemeliharaan Jalan Kabupaten Di Wilayah Perkotaan,” Rekayasa Sipil, vol. 10, no. 1, pp. 1-9, 2016.

[3] H. Rahmad, S. Ria A.A., dan Sumino, "Analisa Penentuan Urutan Prioritas Pemeliharaan Jalan," Tesis, Institut Teknologi Sepuluh Nopember, 2016.

[4] S. P. Munthe, A. A. G. Kartika, dan B. Rahardjo, "Penentuan Prioritas Pemeliharaan Jalan Nasional di Kabupaten Manokwari," Pros. Seminar Nasional Manajemen Teknologi. XIV, pp. 1-9, 2011.

[5] I. S. Mochtar dan Dirgolaksono, "Sistem Penilaian Perkerasan Jalan Untuk Penentuan Prioritas Penanganan," 2006.

[6] Djoko Sulistiono, Ami Asparini, A.F.M, S. M "Survai Visual Untuk Penilaian Kondisi Jalan," Prosiding Seminar Nasional Aplikasi Prasarana Wilayah, pp. 127-132, 2011.

[7] R. Melinda dan C. A. Prastyanto, "Evaluasi Nilai Distribusi Beban As Kendaraan Berdasarkan Data Aktual di Lapangan untuk Kendaraan dengan Konfigurasi Sumbu 1.2 H dan 1.2+2.2," J. Apl. Tek. Sipil, vol. 17, no. 1, p. 34, 2019.

[8] A. Arifin dan H. Sulistiyono, "Penentuan Skala Prioritas Penanganan Jalan Kota Di Kota Mataram," J. Sains Teknol. Lingkung., vol. 1, no. 2, pp. 31-37, 2015. 
Tabel 2. Contoh Pengisian Nilai Visual Perkerasan Jalan dan Drainase

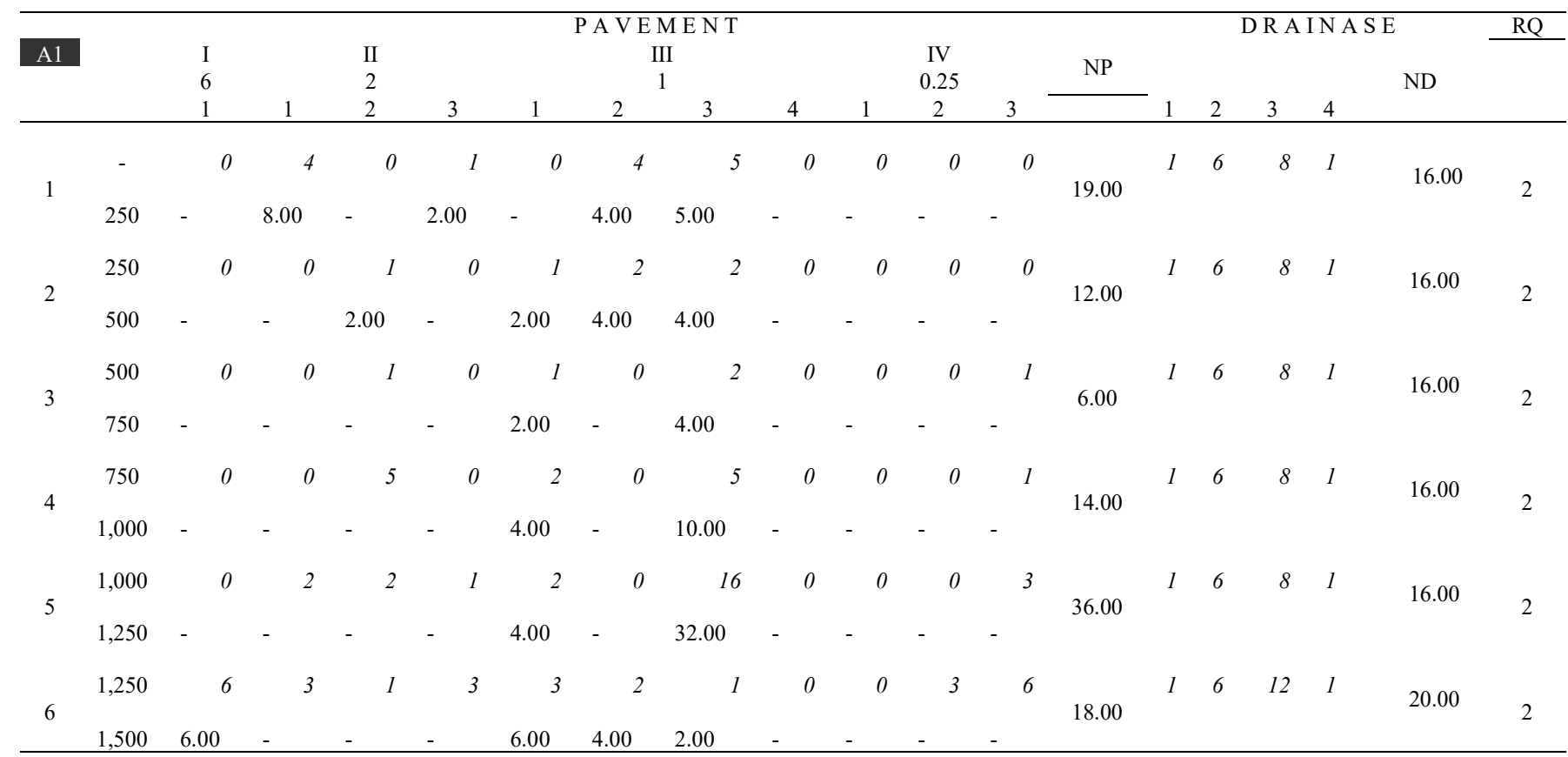

Sumber : I. S. Mochtar dan Dirgolaksono [5]

Tabel 6. Nilai EAL maksimum ruas jalan Aikakeu Laran

\begin{tabular}{|c|c|c|c|c|c|c|c|c|c|c|c|}
\hline $\begin{array}{c}\text { Konfigurasi } \\
\text { Sumbu dan Type }\end{array}$ & $\begin{array}{c}\text { Jumlah } \\
\text { Kendaraan } \\
\text { Perminggu }\end{array}$ & $\begin{array}{l}\text { Berat } \\
\text { Kosong } \\
\text { (Ton) }\end{array}$ & $\begin{array}{c}\text { Berat } \\
\text { Muatan } \\
\text { Maksimum } \\
\text { (Ton) } \\
\end{array}$ & $\begin{array}{l}\text { Berat Total } \\
\text { Maksimum } \\
\quad \text { (Ton) }\end{array}$ & $\begin{array}{c}\text { UE } 18 \\
\text { KSAL } \\
\text { Kosong }\end{array}$ & $\begin{array}{c}\text { UE } 18 \\
\text { KSAL } \\
\text { Maksimum }\end{array}$ & $\begin{array}{c}\text { EAL } \\
\text { Muatan }\end{array}$ & $\begin{array}{l}\text { Konfigurasi } \\
\text { Roda } \\
\text { Kendaraan }\end{array}$ & \multicolumn{3}{|c|}{$\begin{array}{c}\text { Persentase } \\
\text { Konfigurasi Beban }\end{array}$} \\
\hline $1.1 \mathrm{MP}$ & 2099.5 & 1.5 & 0.5 & 2 & 0.0001 & 0.0004 & 0.9145 & $\sigma$ & $50 \%$ & $50 \%$ & \\
\hline 1.2 Bus & 35 & 3 & 6 & 9 & 0.0011 & 0.2628 & 9.1991 & 0 & $34 \%$ & $66 \%$ & \\
\hline 1. 2L Truck & 64 & 2.3 & 6 & 8.3 & 0.0003 & 0.1753 & 11.2211 & 0 & $34 \%$ & $66 \%$ & \\
\hline 1. $2 \mathrm{H} \mathrm{Truck}$ & 32 & 4.2 & 14 & 18.2 & 0.0058 & 8.8883 & 284.4266 & 0 & $34 \%$ & $66 \%$ & \\
\hline 1.22 Truck & 97 & 5 & 20 & 25 & 0.0022 & 6.7750 & 657.1738 & $\sigma \infty$ & $25 \%$ & $75 \%$ & \\
\hline T 1.2 - 22 Trailer & 156 & 6.2 & 20 & 26.2 & 0.0017 & 2.2445 & 350.1405 & 50- & $18 \%$ & $28 \%$ & $54 \%$ \\
\hline $\mathrm{T}$ 1.22- 2.2 Trailer & 94.5 & 11 & 34 & 45 & 0.0222 & 25.4142 & 2401.6460 & $\sigma \infty+\infty$ & $18 \%$ & $28 \%$ & $54 \%$ \\
\hline T.1.2 -222 Trailer & 47.5 & 11 & 34 & 45 & 0.0106 & 33.5486 & 1593.5565 & $\sigma 000$ & $18 \%$ & $28 \%$ & $54 \%$ \\
\hline $\mathrm{T} 1.22-222$ Trailer & 44 & 11 & 34 & 45 & 0.0106 & $\begin{array}{l}12.2008 \\
\sum \text { EAL }\end{array}$ & $\begin{array}{c}536.8350 \\
5845.11\end{array}$ & 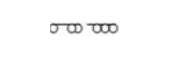 & $18 \%$ & $28 \%$ & $54 \%$ \\
\hline
\end{tabular}


Tabel 7. Nilai EAL Maksimum Ruas Jalan Bebonuk

\begin{tabular}{|c|c|c|c|c|c|c|c|c|c|c|c|}
\hline $\begin{array}{c}\text { Konfigurasi Sumbu } \\
\text { dan Type }\end{array}$ & $\begin{array}{c}\text { Jumlah } \\
\text { Kendaraan } \\
\text { Perminggu }\end{array}$ & $\begin{array}{c}\text { Berat } \\
\text { Kosong } \\
\text { (Ton) }\end{array}$ & $\begin{array}{c}\text { Berat } \\
\text { Muatan } \\
\text { Maksimum } \\
\text { (Ton) } \\
\end{array}$ & $\begin{array}{l}\text { Berat Total } \\
\text { Maksimum } \\
\quad \text { (Ton) }\end{array}$ & $\begin{array}{c}\text { UE } 18 \\
\text { KSAL } \\
\text { Kosong }\end{array}$ & $\begin{array}{c}\text { UE } 18 \\
\text { KSAL } \\
\text { Maksimum }\end{array}$ & $\begin{array}{c}\text { EAL } \\
\text { Muatan } \\
\text { Perminggu }\end{array}$ & $\begin{array}{l}\text { Konfigurasi } \\
\text { Roda Truck }\end{array}$ & \multicolumn{3}{|c|}{$\begin{array}{c}\text { Persentase } \\
\text { Konfigurasi Beban }\end{array}$} \\
\hline $1.1 \mathrm{MP}$ & 6306 & 1.5 & 0.5 & 2 & 0.0001 & 0.0004 & 2.7467 & $\sigma$ & $50 \%$ & $50 \%$ & \\
\hline 1. 2 Bus & 37 & 3 & 6 & 9 & 0.0011 & 0.2628 & 9.7247 & $\sigma$ & $34 \%$ & $66 \%$ & \\
\hline 1. 2L Truck & 250.5 & 2.3 & 6 & 8.3 & 0.0003 & 0.1753 & 43.9199 & $\sigma$ & $34 \%$ & $66 \%$ & \\
\hline 1. $2 \mathrm{H}$ Truck & 148 & 4.2 & 14 & 18.2 & 0.0058 & 8.8883 & 1315.4732 & $\sigma-\infty$ & $34 \%$ & $66 \%$ & \\
\hline 1.22 Truck & 210.5 & 5 & 20 & 25 & 0.0022 & 6.7750 & 1426.1349 & & $25 \%$ & $75 \%$ & \\
\hline T 1.2 - 22 Trailer & 22 & 6.2 & 20 & 26.2 & 0.0017 & 2.2445 & 49.3788 & & $18 \%$ & $28 \%$ & $54 \%$ \\
\hline $\mathrm{T}$ 1.22- 2.2 Trailer & 34.5 & 11 & 34 & 45 & 0.0293 & 33.5486 & 1157.4252 & $\sigma \infty-\infty$ & $18 \%$ & $28 \%$ & $54 \%$ \\
\hline T.1.2 -222 Trailer & 23 & 11 & 34 & 45 & 0.0106 & 33.5486 & 771.6168 & 00000 & $18 \%$ & $28 \%$ & $54 \%$ \\
\hline T 1.22-222 Trailer & 22 & 11 & 34 & 45 & 0.0106 & $\begin{array}{l}12.2008 \\
\sum \mathrm{EAL}\end{array}$ & $\begin{array}{c}268.4175 \\
5044.84\end{array}$ & $\begin{array}{l}500000 \\
\text { Perminggu }\end{array}$ & $18 \%$ & $28 \%$ & $54 \%$ \\
\hline
\end{tabular}

Tabel 8. Nilai EAL Maksimum Ruas Jalan Comoro

\begin{tabular}{|c|c|c|c|c|c|c|c|c|c|c|c|c|}
\hline $\begin{array}{c}\text { Konfigurasi } \\
\text { Sumbu dan } \\
\text { Type }\end{array}$ & $\begin{array}{c}\text { Jumlah } \\
\text { Kendaraan } \\
\text { Perminggu }\end{array}$ & $\begin{array}{c}\text { Berat } \\
\text { Kosong } \\
\text { (Ton) }\end{array}$ & $\begin{array}{c}\text { Berat } \\
\text { Muatan } \\
\text { Maksimum } \\
\text { (Ton) }\end{array}$ & $\begin{array}{c}\text { Berat } \\
\text { Total } \\
\text { Maksimu } \\
\text { m (Ton) }\end{array}$ & $\begin{array}{l}\text { UE } 18 \\
\text { KSAL } \\
\text { Kosong }\end{array}$ & $\begin{array}{c}\text { UE } 18 \\
\text { KSAL } \\
\text { Maksimum }\end{array}$ & $\begin{array}{c}\text { EAL } \\
\text { Muatan } \\
\text { Perminggu }\end{array}$ & $\begin{array}{l}\text { Konfigurasi } \\
\text { Roda Truck }\end{array}$ & \multicolumn{4}{|c|}{$\begin{array}{c}\text { Persentase Konfigurasi } \\
\text { Beban }\end{array}$} \\
\hline $1.1 \mathrm{MP}$ & 49274 & 1.5 & 0.5 & 2 & 0.0001 & 0.0004 & 21.4624 & \multirow[b]{2}{*}{$\sigma 0$} & $50 \%$ & $50 \%$ & & \\
\hline 1.2 Bus & 195.5 & 3 & 6 & 9 & 0.0011 & 0.2628 & 51.3834 & & $34 \%$ & $66 \%$ & & \\
\hline 1.2 L Truck & 87 & 2.3 & 6 & 8.3 & 0.0003 & 0.1753 & 15.2536 & $\sigma 0$ & $34 \%$ & $66 \%$ & & \\
\hline 1.2 H Truck & 83 & 4.2 & 14 & 18.2 & 0.0058 & 8.8883 & 737.7316 & \multirow{2}{*}{$\begin{array}{ll}\sigma & 0 \\
\sigma & 0\end{array}$} & $34 \%$ & $66 \%$ & & \\
\hline 1.22 Truck & 88 & 5 & 22 & 27 & 0.0139 & 63.8678 & 5620.3692 & & $34 \%$ & $66 \%$ & & \\
\hline $1.2+2.2$ Trailer & 46 & 6.4 & 25 & 31.4 & 0.0025 & 7.1424 & 328.5485 & $\sigma \infty$ & $16 \%$ & $36 \%$ & $24 \%$ & $24 \%$ \\
\hline T.1.22-2 & 76 & 6.4 & 25 & 31.4 & 0.0020 & 5.5496 & 421.7675 & 0000 & $18 \%$ & $28 \%$ & $54 \%$ & \\
\hline $\mathrm{T} 1.2-22$ & 54.5 & 6.4 & 25 & 31.4 & 0.0020 & 5.5496 & 302.4517 & $\begin{array}{l}\sigma \infty-0 \\
\sigma 0-\infty\end{array}$ & $18 \%$ & $28 \%$ & $54 \%$ & \\
\hline T1.22-22 & 102 & 10 & 32 & 42 & 0.0182 & 23.7606 & 2423.5830 & \multirow{2}{*}{$\omega_{\infty}^{\infty}$} & $18 \%$ & $28 \%$ & $54 \%$ & \\
\hline T1.2-222 & 58 & 11 & 34 & 45 & 0.0293 & 33.5486 & 1945.8163 & & $18 \%$ & $28 \%$ & $54 \%$ & \\
\hline \multirow[t]{2}{*}{ T.1.22-222 } & 40 & 11 & 34 & 45 & 0.0106 & 12.2008 & 488.0319 & एक & $18 \%$ & $28 \%$ & $54 \%$ & \\
\hline & & & & & & $\sum \mathrm{EAL}$ & 12356.40 & Perminggu & & & & \\
\hline
\end{tabular}

Tabel 9. Nilai EAL Maksimum Ruas Jalan Becora

\begin{tabular}{|c|c|c|c|c|c|c|c|c|c|c|c|c|}
\hline $\begin{array}{l}\text { Konfigurasi } \\
\text { Sumbu dan }\end{array}$ & $\begin{array}{c}\text { Jumlah } \\
\text { Kendaraan }\end{array}$ & $\begin{array}{c}\text { Berat } \\
\text { Kosong }\end{array}$ & $\begin{array}{c}\text { Berat } \\
\text { Muatan } \\
\text { Maksimum }\end{array}$ & $\begin{array}{l}\text { Berat Total } \\
\text { Maksimum }\end{array}$ & $\begin{array}{l}\text { UE } 18 \\
\text { KSAL }\end{array}$ & $\begin{array}{c}\text { UE } 18 \\
\text { KSAL } \\
\text { Maksimum }\end{array}$ & $\begin{array}{c}\text { EAL } \\
\text { Muatan }\end{array}$ & \multirow[t]{2}{*}{$\begin{array}{l}\text { Konfigurasi } \\
\text { Roda Truck }\end{array}$} & \multicolumn{4}{|c|}{$\begin{array}{c}\text { Persentase Konfigurasi } \\
\text { Beban }\end{array}$} \\
\hline $1.1 \mathrm{MP}$ & 17941 & 1.5 & 0.5 & 2 & 0.0001 & 0.0004 & 7.8146 & & \multirow{2}{*}{$\begin{array}{l}50 \% \\
34 \%\end{array}$} & $50 \%$ & & \\
\hline 1.2 Bus & 227 & 3 & 6 & 9 & 0.0011 & 0.2628 & 59.6625 & $\sigma 0$ & & $66 \%$ & & \\
\hline 1.2 L Truck & 722 & 2.3 & 6 & 8.3 & 0.0003 & 0.1753 & 126.5876 & $\sigma 0$ & $34 \%$ & $66 \%$ & & \\
\hline 1.2 H Truck & 259 & 4.2 & 14 & 18.2 & 0.0058 & 8.8883 & 2302.0781 & $\sigma 0$ & $34 \%$ & $66 \%$ & & \\
\hline 1.22 Truck & 62.5 & 5 & 22 & 27 & 0.0212 & 63.8678 & 3991.7395 & $\sigma \omega$ & $25 \%$ & $75 \%$ & & \\
\hline $1.2+2.2$ Trailer & 40 & 6.4 & 25 & 31.4 & 0.0025 & 7.1424 & 285.6943 & $\sigma 0 \sigma 0$ & $16 \%$ & $36 \%$ & $24 \%$ & $24 \%$ \\
\hline T.1.22-2 & 19.5 & 6.4 & 25 & 31.4 & 0.0020 & 5.5496 & 108.2167 & $\sigma \infty-0$ & $18 \%$ & $28 \%$ & $54 \%$ & \\
\hline $\mathrm{T} 1.2-22$ & 39.5 & 6.4 & 25 & 31.4 & 0.0020 & 5.5496 & 219.2081 & \%० & $18 \%$ & $28 \%$ & $54 \%$ & \\
\hline T1.22-22 & 20 & 10 & 32 & 42 & 0.0182 & 23.7606 & 475.2124 & ow & $18 \%$ & $28 \%$ & $54 \%$ & \\
\hline T1.2-222 & 12.5 & 11 & 34 & 45 & 0.0293 & 33.5486 & 419.3570 & \%० & $18 \%$ & $28 \%$ & $54 \%$ & \\
\hline T.1.22-222 & 0.5 & 11 & 34 & 45 & 0.0106 & 33.5486 & 16.7743 & गळ & $18 \%$ & $28 \%$ & $54 \%$ & \\
\hline & & & & & & $\sum \mathrm{EAL}$ & 8012.35 & Perminggu & & & & \\
\hline
\end{tabular}


Lampiran 1. Contoh Form Penilaian Perkerasan Jalan dan Drainase

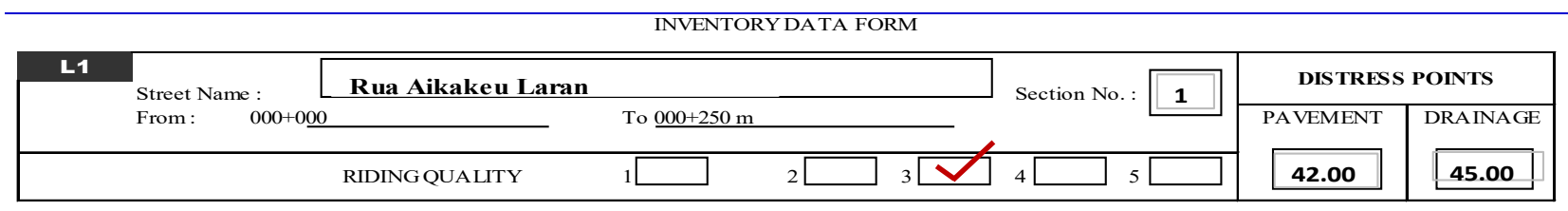

\begin{tabular}{|c|c|c|c|c|c|c|c|}
\hline & CONDITION & \multicolumn{5}{|c|}{ EX E ENT } & SEVERITY \\
\hline \multirow{4}{*}{ I } & \multirow{4}{*}{ POTHOLES } & NONE & $0-10 \%$ & $10-30 \%$ & $30-60 \%$ & $>60 \%$ & AREA \\
\hline & & & 3 & 6 & 15 & (24) & $>7,5 \mathrm{~cm}$ in depth \\
\hline & & & 2 & 4 & 10 & 16 & $2,5-7,5 \mathrm{~cm}$ in depth \\
\hline & & $\mathbf{0}$ & 1 & 2 & 5 & 8 & $<2,5 \mathrm{~cm}$ in depth \\
\hline \multirow{12}{*}{ II } & \multirow{4}{*}{ RA VELING/WEATHERING } & NONE & $0-10 \%$ & $10-30 \%$ & $30-60 \%$ & $>60 \%$ & AREA \\
\hline & & & 3 & 6 & 15 & 24 & highly pitted/rough \\
\hline & & & 2 & 4 & 10 & 16 & some small/pit \\
\hline & & 0 & (1) & 2 & 5 & 8 & minor loss \\
\hline & \multirow{4}{*}{ ALLIGATOR CRACKING } & NONE & $0-10 \%$ & $10-30 \%$ & $30-60 \%$ & $>60 \%$ & AREA \\
\hline & & & 3 & 6 & 15 & 24 & spalled and loose \\
\hline & & & 2 & 4 & 10 & 16 & spalled ang tight \\
\hline & & $\mathbf{0}$ & 1 & 2 & 5 & 8 & hair line \\
\hline & \multirow{4}{*}{ PROFILE DISTORTION } & NONE & $0-10 \%$ & $10-30 \%$ & $30-60 \%$ & $>60 \%$ & AREA \\
\hline & & & 3 & 6 & 15 & 24 & with cracks and holes \\
\hline & & & 2 & 4 & 10 & 16 & with cracking \\
\hline & & $\mathbf{0}$ & 12 & 2 & 5 & 8 & plastic weaving \\
\hline & \multirow{4}{*}{ BLOCK CRACKING } & NONE & $0-10 \%$ & $10-30 \%$ & $30-60 \%$ & $>60 \%$ & AREA \\
\hline & & & 3 & 6 & 15 & 24 & $>1 \mathrm{~cm}$, spalled \\
\hline & & & 2 & 4 & 10 & 16 & $0,5-1 \mathrm{~cm}$, spalled \\
\hline & & 0 & 1 & 2 & 5 & 8 & $<0,5 \mathrm{~cm}$, or sealed \\
\hline & \multirow{4}{*}{ TRANSVERSE CRACKING } & NONE & $0-10 \%$ & $10-30 \%$ & $30-60 \%$ & $>60 \%$ & LENGTH \\
\hline & & & 3 & 6 & 15 & 24 & $>2,5 \mathrm{~cm}$, spalled, full \\
\hline & & & 2 & 4 & 10 & 16 & $0,5-2,5 \mathrm{~cm}$, spalled, half \\
\hline & & о & 10 & 2 & 5 & 8 & $<0,5 \mathrm{~cm}$, sealed, part \\
\hline & \multirow{4}{*}{ LONGITUDINAL CRACKING } & NONE & $0-10 \%$ & $10-30 \%$ & $30-60 \%$ & $>60 \%$ & AREA \\
\hline & & & 3 & 6 & 15 & 24 & $>2,5 \mathrm{~cm}$, spalled \\
\hline & & & 2 & 4 & 10 & 16 & $0,5-2,5 \mathrm{~cm}$, spalled \\
\hline & & $\mathbf{0}$ & 1 & 2 & 5 & 8 & $<0,5 \mathrm{~cm}$, or sealed \\
\hline & \multirow{4}{*}{ RUTTING } & NONE & $0-10 \%$ & $10-30 \%$ & $30-60 \%$ & $>60 \%$ & LENGTH \\
\hline & & & (3) & 6 & 15 & 24 & $>2,5 \mathrm{~cm}$, in depth \\
\hline & & & 2 & 4 & 10 & 16 & $0,5-2,5 \mathrm{~cm}$ in depth \\
\hline & & $\mathbf{0}$ & 1 & 2 & 5 & 8 & $<0,5 \mathrm{~cm}$, in depth \\
\hline \multirow{12}{*}{ IV } & \multirow{4}{*}{ EXCESS ASPHALT } & NONE & $0-10 \%$ & $10-30 \%$ & $30-60 \%$ & $>60 \%$ & AREA \\
\hline & & & 3 & 6 & 15 & 24 & little vizible aggr \\
\hline & & & 2 & 4 & 10 & 16 & wheel track smooth \\
\hline & & 0 & 1 & 2 & 5 & 8 & occas. small patches \\
\hline & \multirow{4}{*}{ BITUMINOUS PATCHING } & NONE & $0-10 \%$ & $10-30 \%$ & $30-60 \%$ & $>60 \%$ & AREA \\
\hline & & & 3 & 6 & 15 & 24 & poor condition \\
\hline & & & 2 & 4 & 10 & 16 & fair condition \\
\hline & & $\mathbf{0}$ & 1 & 2 & 5 & 8 & good condition \\
\hline & \multirow{4}{*}{ EDGE DETERIORATION } & NONE & $0-10 \%$ & $10-30 \%$ & $30-60 \%$ & $>60 \%$ & "LENGTH \\
\hline & & & 3 & 6 & 15 & 24 & edge loose $/$ missing \\
\hline & & & 2 & 4 & 10 & 16 & cracked edge jagged \\
\hline & & $\mathbf{0}$ & 1 & 2 & 5 & 8 & cracked edge intact \\
\hline
\end{tabular}

\section{DRAINAGE}

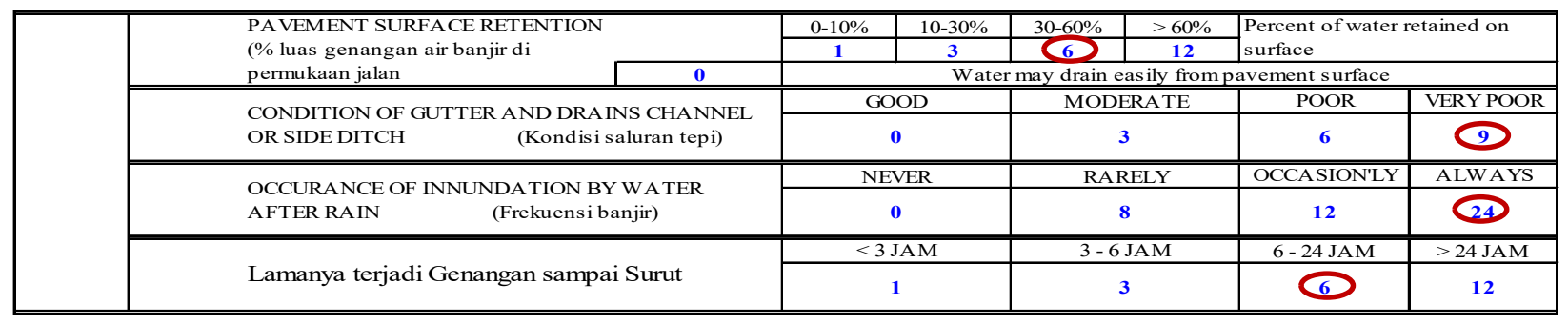


